Artículo científico

Volumen 31(3):517-529. Septiembre-diciembre, 2020 e-ISSN 2215-3608, doi:10.15517/am.v31i3.39726 http://www.revistas.ucr.ac.cr/index.php/agromeso

\title{
Dynamics of severity of coffee leaf rust (Hemileia vastatrix) on Coffee, in Chanchamayo (Junin-Peru) ${ }^{1}$
}

\section{Dinámica de la severidad de la roya (Hemileia vastatrix) en café, en Chanchamayo (Junín-Perú)}

\author{
Leonel Alvarado-Huamán ${ }^{2}$,Ricardo Borjas-Ventura ${ }^{2}$,Viviana Castro-Cepero ${ }^{2}$, Leslie García-Nieves ${ }^{3}$, Jorge \\ Jiménez-Dávalos ${ }^{3}$,Alberto Julca-Otiniano ${ }^{2}$, Luz Gómez-Pando ${ }^{2}$
}

1 Reception: November $21^{\text {st }}, 2019$. Acceptance: March $5^{\text {th }}, 2020$. This work was part of an research carried out by Agriculture and Susteinable Development group of the Peruvian Tropic, and financed by Universidad Nacional Agraria La Molina.

2 Universidad Nacional Agraria La Molina, Facultad de Agronomía, Departamento de Fitotecnia, Grupo de Investigación: Agricultura y Desarrollo Sustentable en el Trópico Peruano, Lima, Perú. lealvarado@lamolina.edu.pe (https://orcid.org/0000-0002-2121-2454), rborjas@lamolina.edu.pe (https://orcid.org/0000-0001-7819-1810), vcastro@lamolina.edu.pe (https://orcid.org/0000-0001-8747-2665), ajo@lamolina.edu.pe (https://orcid.org/0000-0002-3433-9032), luzgomez@lamolina.edu.pe (https://orcid.org/0000-0001-5536-5179).

3 Universidad Nacional Agraria La Molina, Facultad de Agronomía, Departamento de Fitotecnia, Grupo de Investigación: Mutaciones y Biotecnología Vegetal, Lima, Perú. nieves9420@gmail.com (https://orcid.org/0000-0001-7804-9005), jjimenezd@lamolina.edu.pe (https:// orcid.org/0000-0002-2366-6310).

\begin{abstract}
Introduction. Coffee (Coffea arabica L.) is an important crop in producing countries like Peru, where approximately two million families depend on its production, distribution, and marketing. But in recent years, climate change has increased the presence of coffee leaf rust - CLR (H. vastatrix), a disease that has decreased Peruvian production by up to $27 \%$. Objective. Monitor the severity of CLR in different genotypes of coffee cv. Typica from April-2017 to March-2018. Material and methods. The experiment was carried out in the coffee germplasm bank at the Development Regional Institute (IRD)-Selva of the Universidad Nacional Agraria La Molina. The severity and the area under the disease progress curve (AUDPC) in the lower, middle, and upper part of coffee trees were quantified. Result. There was high severity and AUDPC in the dry season (low precipitation) compared to the rainy season (high precipitation). Severity and AUDPC gradually decreased from the bottom to the top of the plant (lower>middle>upper). Also, UNACAF-24A, UNACAF-16, UNACAF-158, and UNACAF-162 genotypes stood out by showing lowest severity (0-1.1\%) and AUDPC (0-714) in the experiment. Conclusion. In this experiment, the genotypes in dry season presented high peaks of severity and UDPC of CLR, meanwhile, in rainy season the presence of CLR was lower. However, in both seasons, severity and AUDPC gradually decreased from the lower third to the upper thirf of the plant. Finally, UNACAF-24A, UNACAF-16, UNACAF-158, and UNACAF-162 presented the lowest degrees of severity of CLR.
\end{abstract}

Keywords: Coffee Leaf Rust, Coffea arabica, disease tolerance, area under the disease progress curve.

\section{Resumen}

Introducción. El café es un cultivo importante en los países productores como el Perú, donde aproximadamente dos millones de familias dependen de su producción, distribución y comercialización. En los últimos años, el cambio 
climático ha aumentado la presencia de la roya del café (H. vastatrix), una enfermedad que ha disminuido hasta en un 27 \% la producción peruana. Objetivo. Monitorear la severidad de la roya del café en diferentes accesiones de café cv. Typica, desde abril 2017 hasta marzo 2018. Materiales y métodos. El experimento se llevó a cabo en el banco de germoplasma de café en el Instituto Regional de Desarrollo (IRD)-Selva de la Universidad Nacional Agraria La Molina. Se cuantificó la severidad y el área bajo la curva del progreso de la enfermedad (ABCPE) en la parte baja, media y alta de las plantas de café. Resultados. Hubo alta severidad y ABCPE en la estación seca en comparación con la estación húmeda. La severidad y el ABCPE disminuyeron gradualmente desde la parte baja hacia la parte alta de la planta (parte baja $>$ media $>$ alta). Las accesiones UNACAF-24A, UNACAF-16, UNACAF-158 y UNACAF-162 tuvieron la menor severidad (0-1,1\%) y ABCPE (0-714) en el experimento. Conclusión. En este experimento, en la estación seca (estación con poca precipitación) los genotipos presentaron altos picos de severidad y ABCPE de roya, mientras que en la estación lluviosa la presencia de la roya del café fue menor. Sin embargo, en ambas estaciones, la severidad y ABCPE disminuyeron gradualmente desde el tercio inferior hasta el tercio superior de la planta. Finalmente, UNACAF-24A, UNACAF-16, UNACAF-158 y UNACAF-162, presentaron los menores grados de severidad y de ABCPE.

Palabras claves: roya del café, Coffea arabica, tolerancia a enfermedades, área bajo la curva del progreso de la enfermedad.

\section{Introduction}

According to the International Coffee Organization (ICO, 2019), two types of coffee are marketed in the world: Coffea arabica (Arabica coffee) and Coffea canephora (Robusta). The first is the predominant one and represents $61.5 \%$ of all coffee sold worldwide. Likewise, coffee production has great economic and social importance in producing nations (ICO, 2019). For example, it is estimated that two million families depend on their production, distribution and commercialization in Peru (Díaz y Carmen, 2017). In addition, coffee exports generate significant income for small farmers, and are the economic engine of producing countries.

Despite its economic and social importance, coffee production has key problems such as coffee leaf rust (CLR) (Hemileia vastatrix) whose presence is been exacerbated by the climate change (Rice, 2018). Global losses of around $50 \%$ putting the small coffee producer at risk were reported (Capucho et al., 2013; Zambolim, 2016) and Capucho et al. (2013). Detected in 1869 in Ceylon, CLR is the most important coffee disease (Coffea arabica), whose presence is recorded in all continents where coffee is grown (Talhinhas et al., 2017). Also, in countries like Peru, its incidence can reach 74-94\% (Alvarado et al., 2017; Julca et al., 2018). Once it infects the coffee leaves, the CLR causes its fall, decreasing the yield around $35 \%$ (Talhinhas et al., 2017), although these values are variable according to the geographical region. For example, in 2007 there was a loss in yield in Colombia of $31 \%$ (Avelino et al., 2015), in Peru $27 \%$ (INEI, 2014), Brazil from 30 to $50 \%$ (Zambolim, 2016) and Centro America from 10 to $16 \%$ (Avelino et al., 2015).

The impact of the CLR is associated with the type of coffee cultivar used, local climatic conditions, shade, moisture, wind and fruit load (Julca et al., 2013; Toniutti et al., 2017). Regarding to fruit load, in years of high yield, much phenolic compounds are allocated from leaves to the fruits (Julca et al., 2013) decreasing the defense of the plant. The phenolic compounds are considered anti-fungal compound (Subroto et al., 2019).

In recent years, much research has been carried out to try to diminish the severe impact of this disease on coffee (Avelino et al., 2004). However, little attention has been paid to monitoring the dynamics of H. vastatrix during all phenological stages of the coffee plant, for example Santana et al. (2015) determined, in general, high incidence of CLR in days with fewer precipitation; they also noticed differentiated response amount the cultivars studied 
(Catuai, Mundo Novo and IPR 106). High presence of CLR from April to August (in 2016, 2017 and 2018), was observed by Matos et al. (2019), however, CLR decreased from September to December.

An adequate management system of CLR needs a deep knowledge of its behavior in local sites since its incidence and severity are influenced by microclimatic conditions. Furthermore, determining the dynamics of CLR is very important because it allows the design of adequate strategies to develop or improve systems to predict the presence of this disease (Chemura et al., 2018), evaluate the efficiency of pesticides (Honorato-Junior et al., 2015) and determine the tolerance of different coffee genotypes (Dias et al., 2019).

The Typica cultivar is one of the most widely used in Peru (MINAGRI, 2019) due to its tolerance to adverse conditions (e.g. drought and high temperature), but is very sensitive to CLR. It is also common practice for farmers to have several varieties mixed in the same plantation. During a national sampling of coffee varieties in 2009, many farmers indicated that some Typica cultivars showed some tolerance to H. vastatrix. In this regard, Klein et al. (2003) reported the existence of cross-pollination in coffee. However, this supposed acquired tolerance of coffee cv Typica has not yet been studied. In this context, an experiment was carried out to quantify the dynamics of the severity of $H$. vastatrix in coffee cv. Typica under Peruvian conditions and to determine whether some Typica cultivars collected in different Peruvian regions have tolerance to coffee leaf rust (CLR).

In this context, this work aimed was to monitor the severity of CLR in different genotypes of coffee cv Typica from April-2017 to March-2018.

\section{Material and methods}

The evaluation was carried out from April-2017 until March-2018 in the coffee germplasm bank in the Regional Development Institute (IRD)-Selva of the Universidad Nacional Agraria La Molina (UNALM). The study site was located in Chanchamayo, Junin-Lima (Peru) (altitude $965 \mathrm{~m}, 11^{\circ} 05.790^{\prime} \mathrm{S}$ and $75^{\circ} 20.969^{\prime} \mathrm{W}$ ). Within the germplasm bank, the genotypes studied of Coffea arabica cv. Typica were spaced $2 \times 1 \mathrm{~m}$, and each genotype was in a row. The shade trees (Inga sp.) were spaced $12 \times 12 \mathrm{~m}$. All plants were about ten years old and had only one stem. In this sense, all plants were sown in the same time. Management was conventional, meaning that herbicides and insecticides were used to control weeds and some pests. The presence of CLR was not controlled with any method.

During the study, the rainy (high rainfall) (September to January) and dry (lower rainfall) seasons were determined (April-May-June-July-August-2017 and February-March-2018). The soil samples were collected to $20 \mathrm{~cm}$ depth. As for the chemical and physical characteristics of the soil, it presented a pH of 5.7 and CEC 16.80 $\mathrm{cmol}_{(+)} \mathrm{kg}^{-1}$. The content of interchangeable calcium, magnesium and potassium was $8.2,1.23$ and $0.34 \mathrm{cmol}_{(+)} \mathrm{kg}^{-}$ ${ }^{1}$, respectively. The base saturation percentage was $59 \%$. The texture class was sandy loam. In terms of climatic conditions, two seasons were identified: dry season (precipitation around $100 \mathrm{~mm}$ per month) and rainy season (precipitation $>100 \mathrm{~mm}$ per month) (Marca-Huamancha et al., 2018). The annual mean temperature was $23.1^{\circ} \mathrm{C}$.

The severity of CLR and the area under the disease progression curve (AUDPC) were evaluated. Both are variables related to level of damage in the plant yield.

The severity of CLR was measured in the upper, middle and lower sections of the coffee trees, taking different branches at each sampling date. In each branch (within each section), severity was determined according to the scale showing in Figure 1 (Julca et al., 2019). The area under the disease progression curve (AUDPC) was also calculated (Madden et al., 2007). All plants showed a natural incidence of CLR at the beginning of the experiment.

The experiment had 32 treatments with 5 replicates (Table 1). A completely random design was used. The multiple comparison was made with the Scott-Knott test (95\%). The AGROSTAT software was used to analyze the data (Barbosa and Junior, 2010). 

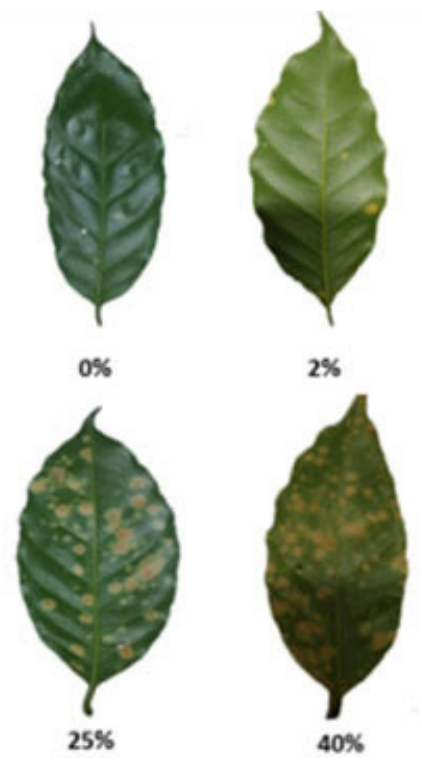
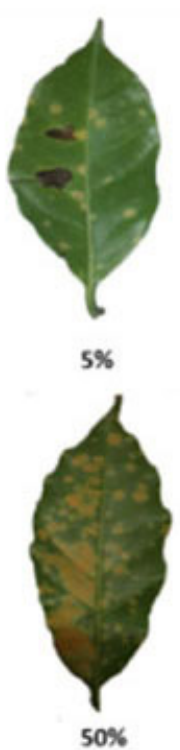
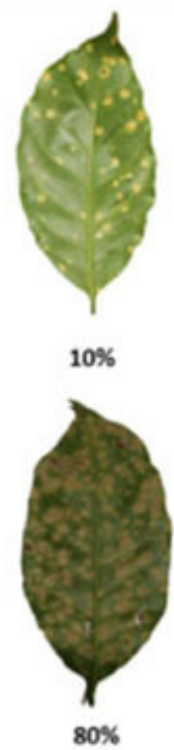

Figure 1. Scale used to quantify the severity of $H$. vastatrix on Coffea arabica cv. Typica in Chanchamayo, Junin-Peru, from April 2017 to March 2018.

Figura 1. Escala usada para cuantificar la severidad de H. vastatrix en café cv Typica en Chanchamayo, Junín-Perú, de Abril 2017 a Marzo 2018.

Table 1. Genotypes studied in the quantification of the severity of H. vastatrix on Coffea arabica cv. Typica, in Chanchamayo, JuninPeru, from April 2017 to March 2018.

Tabla 1. Accesiones estudiadas en la cuantificación de la severidad de H. vastatrix en café cv Typica, en Chanchamayo, Junín-Perú, de Abril 2017 a Marzo 2018.

\begin{tabular}{cccccccc}
\hline Origin & Genotype & Origin & Genotype & Origin & Genotype & Origin & Genotype \\
\hline Piura & UNACAF-97 & Junin & UNACAF-40 & Lambayeque & UNACAF-105 & Cuzco & UNACAF-165 \\
Piura & UNACAF-94 & Junin & UNACAF-36 & San Martin & UNACAF-119 & Huanuco & UNACAF-186 \\
Piura & UNACAF-93 & Junin & UNACAF-27 & Amazonas & UNACAF-128 & Puno & UNACAF-214 \\
Piura & UNACAF-87 & Junin & UNACAF-24 & Amazonas & UNACAF-132 & Puno & UNACAF-216 \\
Piura & UNACAF-86 & Junin & UNACAF-16 & Cajamarca & UNACAF-138 & Puno & UNACAF-218 \\
Piura & UNACAF-81 & Junin & UNACAF-8 & Cajamarca & UNACAF-140 & Puno & UNACAF-226 \\
Piura & UNACAF-76 & Junin & UNACAF-2 & Cuzco & UNACAF-158 & Puno & UNACAF-228 \\
Junín & UNACAF-52 & Lambayeque & UNACAF-104 & Cuzco & UNACAF-162 & Huanuco & UNACAF-199 \\
\hline
\end{tabular}

\section{Results}

The data of the severity of $H$. vastatrix in coffee trees cv Typica in Peruvian conditions showed that all genotypes presented different degrees of severity during the course of the experiment (12 months). In general, the lower, middle and upper parts had the highest presence of CLR in April, May, June, July, August, February and 
March (dry season). Meanwhile, from September to January (rainy season) the severity decreased notably (Figure $2,3,4)$. Within the dry season, the presence of $H$. vastatrix increased significantly in May and June, although its

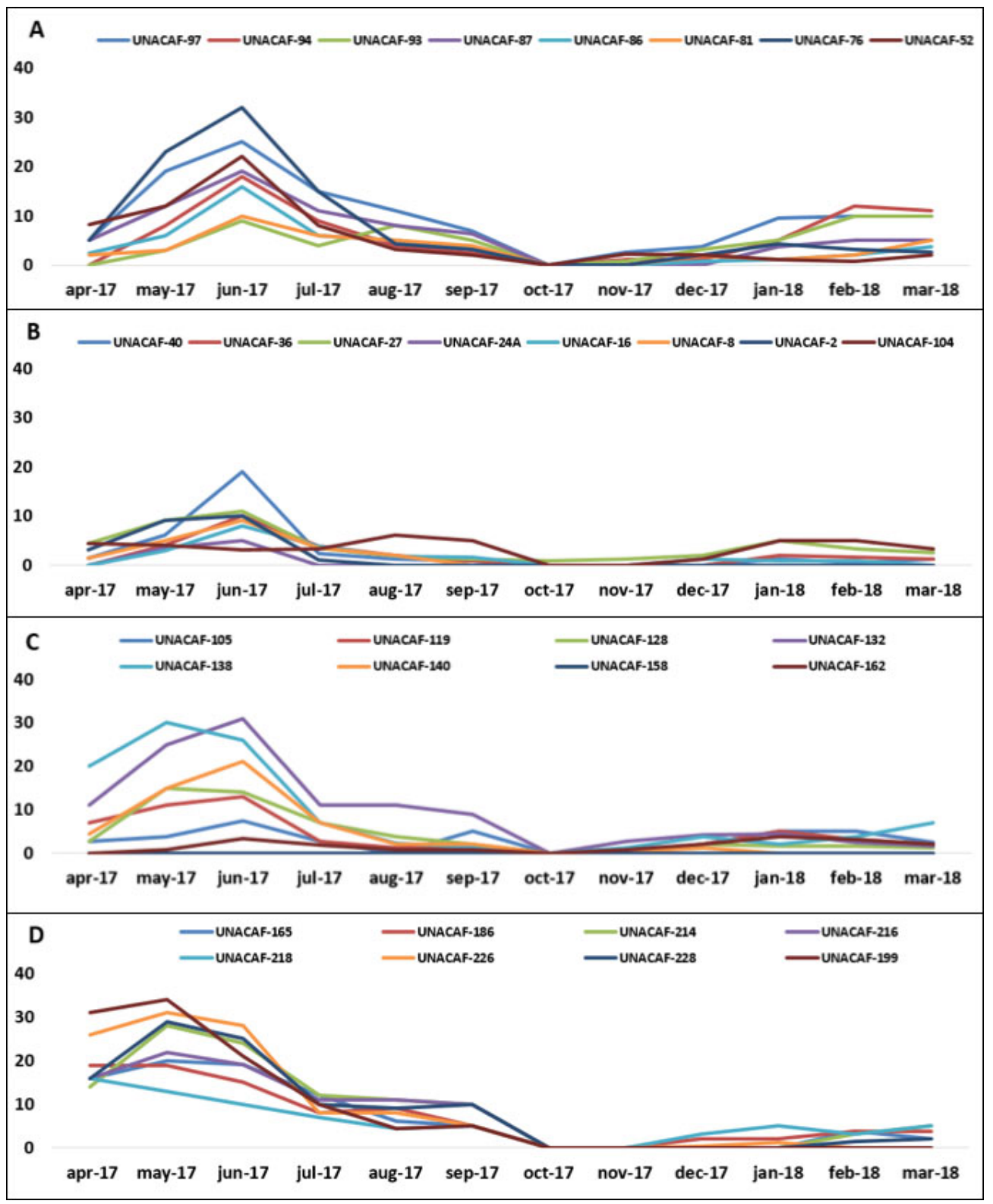

Figure 2. H. vastatrix (\%) severity in the lower section of Coffea arabica tree cv Typica in Chanchamayo, Junin-Peru, from April 2017 to March 2018.

A, B, C, and D show different genotypes of coffee cv Typica in the germplasm of the Universidad Nacional Agraria La Molina.

Figura 2. Severidad de H. vastatrix (\%) en la parte baja de la planta de café cv Typica en Chanchamayo, Junín-Perú, de Abril 2017 a Marzo 2018.

A, B, C y D muestran diferentes accesiones de café cv Typica en el banco de germoplasma de la Universidad Nacional Agraria La Molina. 


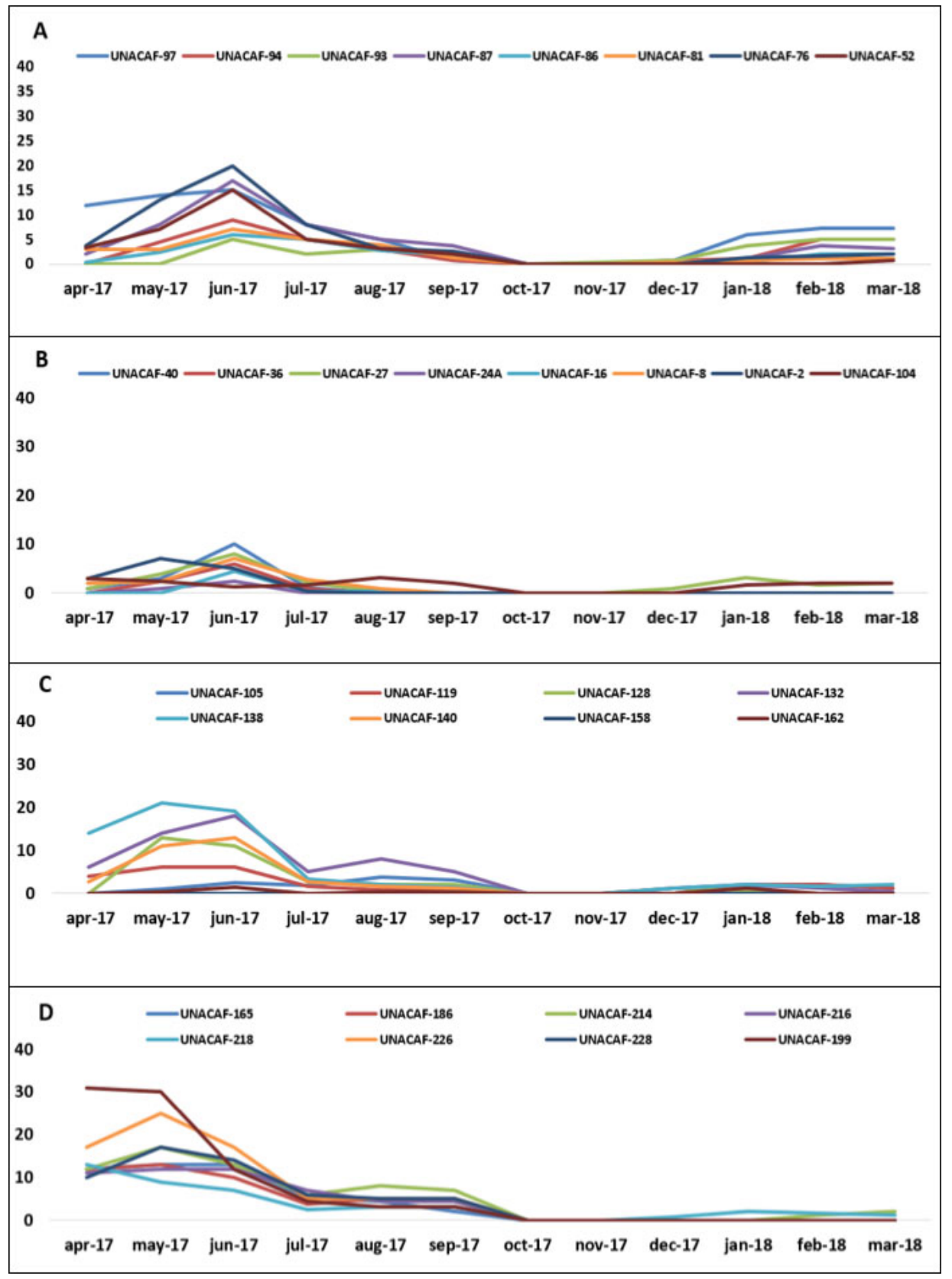

Figure 3. H. vastatrix (\%) severity in the middle section of Coffea arabica tree cv Typica, in Chanchamayo, Junin-Peru, from April 2017 to March 2018.

A, B, C, and D show different genotypes of coffee cv Typica in the germplasm of the Universidad Nacional Agraria La Molina.

Figura 3. Severidad de H. vastatrix (\%) en la parte media de la planta de café cv Typica, en Chanchamayo, Junín-Perú, de Abril 2017 a Marzo 2018.

A, B, C y D muestran diferentes accesiones de café cv Typica en el banco de germoplasma de la Universidad Nacional Agraria La Molina. 


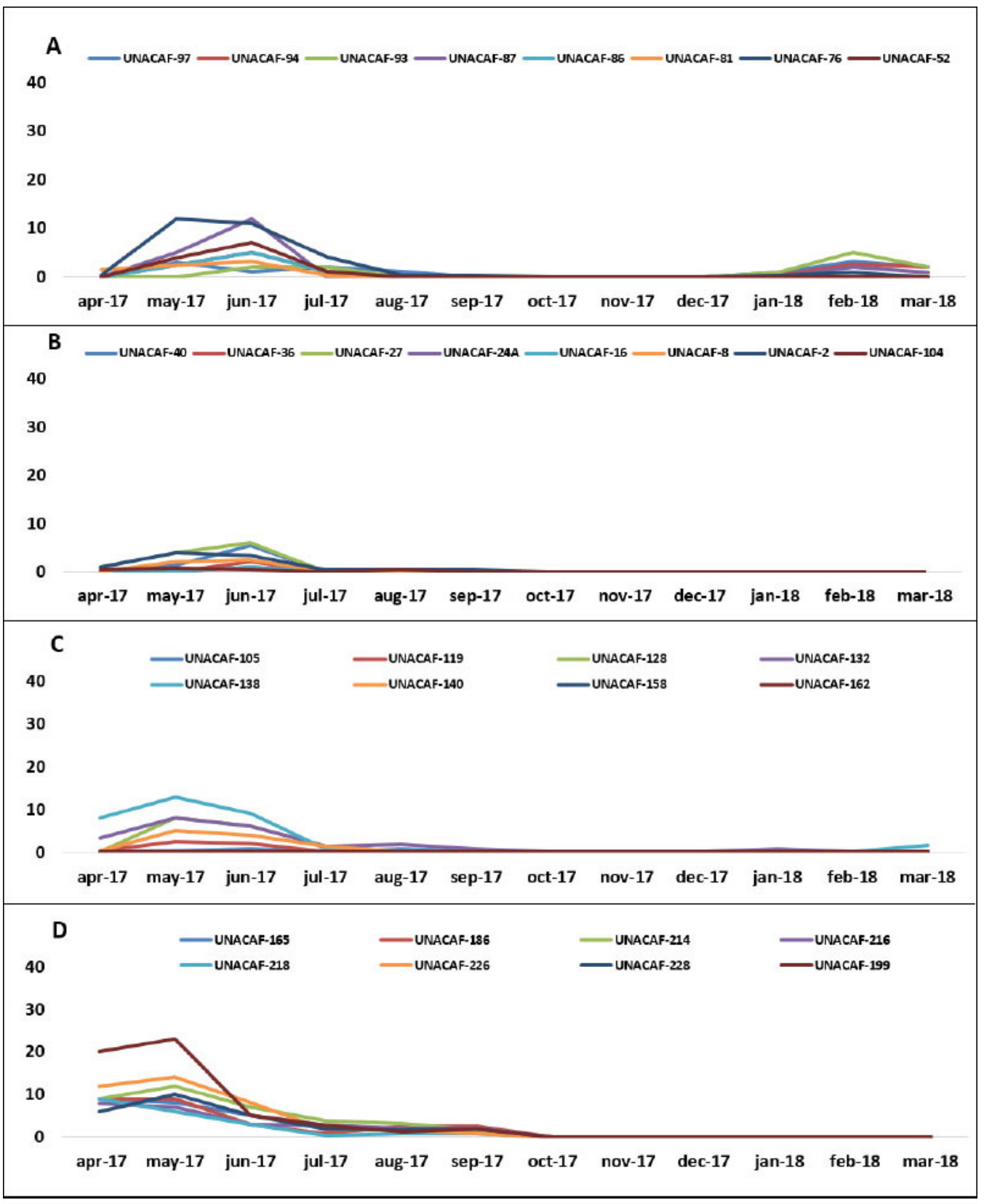

Figure 4. H. vastatrix (\%) severity in the upper section of Coffea arabica tree cv Typica, in Chanchamayo, Junin-Peru, from April 2017 to March 2018.

A, B , C, and D show different genotypes of coffee cv Typica in the germplasm of the Universidad Nacional Agraria La Molina.

Figura 4. Severidad de H. vastatrix (\%) en la parte alta de la planta de café cv Typica, en Chanchamayo, Junín-Perú, de Abril 2017 a Marzo 2018.

A, B, C y D muestran diferentes accesiones de café cv Typica en el banco de germoplasma de la Universidad Nacional Agraria La Molina. 
presence depended on the part of the plant where the measurement was made and the genotype evaluated. In the lower, middle and upper part of the plant, severity reached 32 to $34 \%, 20$ to $30 \%$, and 12 to $23 \%$, respectively. In addition, only in May, UNACAF-199 showed the highest severity values in all parts of the tested plant, for example in the lower, middle and upper section it had $34 \%, 30 \%$, and $23 \%$ (Figure 2-D; Figure 3-D and Figure 4-D).

Throughout the evaluation period (both seasons), the lower part had a greater severity of the disease than the middle part, which in turn was greater than the upper part (Table 2).

In the dry season, the severity of the low, medium and high sections reached $12-14 \%, 11.92 \%$, and $7.43 \%$, respectively (Table 2). When the entire plant was evaluated (lower + medium + upper), it was observed that the UNACAF-199 genotype showed the highest severity value $(11.10 \%)(\mathrm{p} \leq 0.05)$ compared to other genotypes. In the same season, other ones had lower mean values of severity, such as UNACAF-16 (1.11\%), UNACAF-24A (0.6\%), and UNACAF-158 (0\%) ( $\mathrm{p} \leq 0.05)$.

In the rainy season, the low, middle and upper sections showed severity maximum values of $4-4.6 \%, 1.2-1.52$ $\%$ and, 0.4- $0.52 \%$, respectively (Table 2). Likewise, when the whole plant was examined, the highest mean values of severity were found in the genotypes UNACAF-97 (2.12\%), and UNACAF-132 (2.01\%), while the lowest mean values were found in the genotypes UNACAF-40 (0.13\%), UNACAF-36 (0.19\%), UNACAF-24A (0 \%), UNACAF-8 (0 \%), UNACAF-2 (0.30\%), UNACAF-140 (0.33\%), and UNACAF-158 (0\%) (p $\leq 0.05)$.

The data of the area under the disease progression curve (AUDPC) showed that in the dry season, the lower, middle and upper parts of the plant reached values of 2442 to 2715,1890 to 2001, and 1290, respectively (Table 3). When the entire plant was examined, the result showed that UNACAF-99 (5913), UNACAF-226 (5553) and UNACAF-214 (5324) had the highest AUDPC values, while UNACAF-24A (378), UNACAF-16 (714), UNACAF-162 (366), and UNACAF-158 (0) were the lowest. In addition, in the rainy season the lower, middle and upper parts of the plant reached AUDPC values of 735, 324, and 99. When the AUDPC values found at the lower, middle and upper parts were added together, the data showed that UNACAF-97 (1131) had the highest severity value.

\section{Discussion}

Severity of CLR is also highly correlated with its incidence (Julca et al., 2019). Overall, great severity was observed in April 2017, May 2017, June 2017, July 2017, August 2017, February 2018, and March 2018 (dry season) compared to September 2017, October 2017, November 2017, December 2017, and January 2018 (rainy season) throughout the plant (Figure 2,3,4). These results were not expected because severity is highly correlated with high temperature and precipitation (Brinate et al., 2015). The data obtained may be related to fruit loading (Avelino et al., 2004). In this case, in the experimental area, harvesting started in April approximately and that was increasing gradually until ending in June.

Precipitation and temperature can increase the severity of CLR causing high degrees of severity (Haile, 2018; Talhinhas et al., 2017; Toniutti et al., 2017). In this work, within the dry season, in May and June, the severity was higher than in the other months, reaching from $32 \%$ to $34 \%, 20 \%$ to $30 \%$, and $12 \%$ to $23 \%$ in the lower, middle and upper parts, respectively. About 35-40 \% severity of CLR in coffee cv Catuaí Vermelho IAC 81 and Catuaí Vermelho 44 respectively, was reported by Sera et al. (2009) and Carré-Missio et al. (2013).

Regarding the severity of CLR and the area under the disease progression curve (AUDPC) in the lower, middle and upper part, it was observed that, in the rainy and dry seasons (Table 2,3), the severity gradually decreased from the lower to the upper part (lower> middle> upper). This result suggests that in the lower part there are suitable environmental conditions (e.g. shade and moisture) that increase the outbreak of H. vastatrix. In the case of shade, it favors the germination and infection of spore rust (López-Bravo et al., 2012). 
Table 2. H. vastatrix severity in dry and rainy season in lower, middle, and upper part of Coffea arabica tree cv Typica, in Chanchamayo, Junin-Peru, from April 2017 to March, 2018.

Tabla 2. Severidad de H. vastatrix en las estaciones húmeda y seca en la parte baja, media y alta de la planta de café cv Typica, en Chanchamayo, Junín-Perú, de abril 2017 a marzo, 2018.

\begin{tabular}{|c|c|c|c|c|c|c|c|c|}
\hline \multirow[b]{2}{*}{ Genotypes } & \multicolumn{4}{|c|}{ Dry seasons } & \multicolumn{3}{|c|}{ Rainy seasons } & \multirow[b]{2}{*}{ Mean } \\
\hline & Lower & Middle & Upper & Mean & Lower & Middle & Upper & \\
\hline UNACAF-97 & $13.57 \mathrm{a}$ & $9.77 \mathrm{~b}$ & $1.74 \mathrm{~d}$ & $8.36 \mathrm{c}$ & $4.60 \mathrm{a}$ & $1.52 \mathrm{a}$ & $0.16 \mathrm{~b}$ & $2.12 \mathrm{a}$ \\
\hline UNACAF-94 & $8.86 \mathrm{c}$ & $4.49 \mathrm{~d}$ & $1.86 \mathrm{~d}$ & $5.07 \mathrm{e}$ & $1.96 \mathrm{c}$ & $0.56 \mathrm{c}$ & $0.08 \mathrm{~b}$ & $0.87 \mathrm{c}$ \\
\hline UNACAF-93 & $6.29 \mathrm{~d}$ & $2.86 \mathrm{e}$ & $1.57 \mathrm{~d}$ & $3.57 \mathrm{e}$ & $2.80 \mathrm{~b}$ & $1.48 \mathrm{a}$ & $0.16 \mathrm{~b}$ & $1.48 \mathrm{~b}$ \\
\hline UNACAF-87 & $9.29 \mathrm{c}$ & $6.71 \mathrm{c}$ & $2.83 \mathrm{c}$ & $6.28 \mathrm{~d}$ & $2.04 \mathrm{c}$ & $1.00 \mathrm{~b}$ & $0.00 \mathrm{~b}$ & $1.01 \mathrm{c}$ \\
\hline UNACAF-86 & $5.89 \mathrm{~d}$ & $2.94 \mathrm{e}$ & $1.20 \mathrm{~d}$ & $3.34 \mathrm{f}$ & $1.08 \mathrm{~d}$ & $0.44 \mathrm{c}$ & $0.00 \mathrm{~b}$ & $0.51 \mathrm{~d}$ \\
\hline UNACAF-81 & $4.71 \mathrm{e}$ & $3.49 \mathrm{e}$ & $1.05 \mathrm{~d}$ & $3.09 \mathrm{f}$ & $1.40 \mathrm{~d}$ & $0.52 \mathrm{c}$ & $0.00 \mathrm{~b}$ & $0.64 \mathrm{~d}$ \\
\hline UNACAF-76 & $12.17 \mathrm{a}$ & $7.37 \mathrm{c}$ & $4.09 \mathrm{c}$ & $7.88 \mathrm{c}$ & $1.92 \mathrm{c}$ & $0.80 \mathrm{~b}$ & $0.16 \mathrm{~b}$ & $0.96 \mathrm{c}$ \\
\hline UNACAF-52 & $8.03 \mathrm{~d}$ & $4.91 \mathrm{~d}$ & $1.68 \mathrm{~d}$ & $4.88 \mathrm{e}$ & $1.48 \mathrm{~d}$ & $0.40 \mathrm{c}$ & $0.00 \mathrm{~b}$ & $0.63 \mathrm{~d}$ \\
\hline UNACAF-40 & $4.51 \mathrm{e}$ & $2.11 \mathrm{f}$ & $0.97 \mathrm{~d}$ & $2.53 \mathrm{~g}$ & $0.40 \mathrm{e}$ & $0.00 \mathrm{~d}$ & $0.00 \mathrm{~b}$ & $0.13 \mathrm{e}$ \\
\hline UNACAF-36 & $3.23 \mathrm{f}$ & $1.31 \mathrm{f}$ & $0.29 \mathrm{e}$ & $1.61 \mathrm{~g}$ & $0.56 \mathrm{e}$ & $0.80 \mathrm{~b}$ & $0.00 \mathrm{~b}$ & $0.19 \mathrm{e}$ \\
\hline UNACAF-27 & $5.06 \mathrm{e}$ & $2.69 \mathrm{e}$ & $1.57 \mathrm{~d}$ & $3.11 \mathrm{f}$ & $2.04 \mathrm{c}$ & $0.80 \mathrm{~b}$ & $0.00 \mathrm{~b}$ & $0.95 \mathrm{c}$ \\
\hline UNACAF-24 & $1.20 \mathrm{~g}$ & $0.46 \mathrm{~g}$ & $0.14 \mathrm{e}$ & $0.60 \mathrm{~h}$ & $0.00 \mathrm{e}$ & $0.00 \mathrm{~d}$ & $0.00 \mathrm{~b}$ & $0.00 \mathrm{e}$ \\
\hline UNACAF-16 & $2.46 \mathrm{f}$ & $0.74 \mathrm{~g}$ & $0.14 \mathrm{e}$ & $1.11 \mathrm{~h}$ & $0.72 \mathrm{~d}$ & $0.00 \mathrm{~d}$ & $0.00 \mathrm{~b}$ & $0.24 \mathrm{e}$ \\
\hline UNACAF-8 & $2.97 \mathrm{f}$ & $2.14 \mathrm{f}$ & $0.63 \mathrm{e}$ & $1.91 \mathrm{~g}$ & $0.00 \mathrm{e}$ & $0.00 \mathrm{~d}$ & $0.00 \mathrm{~b}$ & $0.00 \mathrm{e}$ \\
\hline UNACAF-2 & $3.29 \mathrm{f}$ & $2.20 \mathrm{f}$ & $1.31 \mathrm{~d}$ & $2.27 \mathrm{~g}$ & $0.00 \mathrm{e}$ & $0.00 \mathrm{~d}$ & $0.08 \mathrm{~b}$ & $0.03 \mathrm{e}$ \\
\hline UNACAF-104 & $4.11 \mathrm{e}$ & $2.20 \mathrm{f}$ & $0.29 \mathrm{e}$ & $2.20 \mathrm{~g}$ & $2.24 \mathrm{c}$ & $0.72 \mathrm{~b}$ & $0.00 \mathrm{~b}$ & $0.99 \mathrm{c}$ \\
\hline UNACAF-105 & $4.34 \mathrm{e}$ & $1.74 \mathrm{f}$ & $0.29 \mathrm{e}$ & $2.12 \mathrm{~g}$ & $2.40 \mathrm{~b}$ & $0.76 \mathrm{~b}$ & $0.00 \mathrm{~b}$ & $1.12 \mathrm{~b}$ \\
\hline UNACAF-119 & $5.74 \mathrm{~d}$ & $3.09 \mathrm{e}$ & $0.69 \mathrm{e}$ & $3.17 \mathrm{f}$ & $1.80 \mathrm{c}$ & $0.64 \mathrm{~b}$ & $0.08 \mathrm{~b}$ & $0.84 \mathrm{c}$ \\
\hline UNACAF-128 & $6.49 \mathrm{~d}$ & $4.09 \mathrm{~d}$ & $2.20 \mathrm{~d}$ & $4.26 \mathrm{e}$ & $1.12 \mathrm{~d}$ & $0.80 \mathrm{~b}$ & $0.00 \mathrm{~b}$ & $0.64 \mathrm{~d}$ \\
\hline UNACAF-132 & $13.31 \mathrm{a}$ & $7.51 \mathrm{c}$ & $2.91 \mathrm{c}$ & $7.91 \mathrm{c}$ & $4.08 \mathrm{a}$ & $1.64 \mathrm{a}$ & $0.32 \mathrm{a}$ & $2.01 \mathrm{a}$ \\
\hline UNACAF-138 & $13.74 \mathrm{a}$ & $9.00 \mathrm{~b}$ & $4,69 \mathrm{~b}$ & $9.14 \mathrm{~b}$ & $1.68 \mathrm{c}$ & $0.92 \mathrm{~b}$ & $0.00 \mathrm{~b}$ & $0.87 \mathrm{c}$ \\
\hline UNACAF-140 & $7.09 \mathrm{~d}$ & $4.40 \mathrm{~d}$ & $1.54 \mathrm{~d}$ & $4.34 \mathrm{e}$ & $0.76 \mathrm{~d}$ & $0.24 \mathrm{c}$ & $0.00 \mathrm{~b}$ & $0.33 \mathrm{e}$ \\
\hline UNACAF-158 & $0.00 \mathrm{~g}$ & $0.00 \mathrm{~g}$ & $0.00 \mathrm{e}$ & $0.00 \mathrm{~h}$ & $0.00 \mathrm{e}$ & $0.00 \mathrm{~d}$ & $0.00 \mathrm{~b}$ & $0.00 \mathrm{e}$ \\
\hline UNACAF-162 & $1.71 \mathrm{~g}$ & $0.31 \mathrm{~g}$ & $0.00 \mathrm{e}$ & $0.67 \mathrm{~g}$ & $1.48 \mathrm{~d}$ & $0.32 \mathrm{c}$ & $0.00 \mathrm{~b}$ & $0.60 \mathrm{~d}$ \\
\hline UNACAF-165 & $11.26 \mathrm{~b}$ & $6.83 \mathrm{c}$ & $3.83 \mathrm{c}$ & $7.31 \mathrm{c}$ & $1.00 \mathrm{~d}$ & $0.40 \mathrm{c}$ & $0.40 \mathrm{a}$ & $0.60 \mathrm{~d}$ \\
\hline UNACAF-186 & $11.09 \mathrm{~b}$ & $6.26 \mathrm{c}$ & $3.49 \mathrm{c}$ & $6.94 \mathrm{c}$ & $1.80 \mathrm{c}$ & $0.88 \mathrm{~b}$ & $0.52 \mathrm{a}$ & $1.07 \mathrm{c}$ \\
\hline UNACAF-214 & $13.89 \mathrm{a}$ & $8.46 \mathrm{~b}$ & $5,00 \mathrm{~b}$ & $9.11 \mathrm{~b}$ & $2.00 \mathrm{c}$ & $1.40 \mathrm{a}$ & $0.32 \mathrm{a}$ & $1.24 \mathrm{~b}$ \\
\hline UNACAF-216 & $11.29 \mathrm{~b}$ & $6.63 \mathrm{c}$ & $3.29 \mathrm{c}$ & $7.07 \mathrm{c}$ & $2.00 \mathrm{c}$ & $0.88 \mathrm{~b}$ & $0.44 \mathrm{a}$ & $1.11 \mathrm{~b}$ \\
\hline UNACAF-218 & $8.37 \mathrm{c}$ & $5.37 \mathrm{c}$ & $2.74 \mathrm{c}$ & $5.50 \mathrm{~d}$ & $2.64 \mathrm{~b}$ & $1.20 \mathrm{a}$ & $0.16 \mathrm{~b}$ & $1.33 \mathrm{~b}$ \\
\hline UNACAF-226 & $14.43 \mathrm{a}$ & $9.86 \mathrm{~b}$ & $5,31 \mathrm{~b}$ & $9.87 \mathrm{~b}$ & $1.32 \mathrm{~d}$ & $1.00 \mathrm{~b}$ & $0.16 \mathrm{~b}$ & $0.83 \mathrm{c}$ \\
\hline UNACAF-228 & $13.20 \mathrm{a}$ & $7.43 \mathrm{c}$ & $3.51 \mathrm{c}$ & $8.05 \mathrm{c}$ & $2.00 \mathrm{c}$ & $1.00 \mathrm{~b}$ & $0.40 \mathrm{a}$ & $1.13 \mathrm{~b}$ \\
\hline UNACAF-199 & $14.34 \mathrm{a}$ & $11.52 \mathrm{a}$ & $7.43 \mathrm{a}$ & $11.10 \mathrm{a}$ & $1.00 \mathrm{~d}$ & $0.64 \mathrm{~b}$ & $0.40 \mathrm{a}$ & $0.68 \mathrm{~d}$ \\
\hline Mean & 7.68 & 4.65 & 2.10 & 4.82 & 1.57 & 0.66 & 0.12 & 0.79 \\
\hline SE & 0.82 & 0.59 & 0.36 & 0.49 & 0.23 & 0.14 & 0.07 & 0.11 \\
\hline SD & 1.83 & 1.31 & 0.80 & 1.08 & 0.52 & 0.31 & 0.15 & 0.24 \\
\hline
\end{tabular}

Different letters within columns indicate statistical differences according to Scott-Knott's test ( $\leq 0.05) /$ Letras diferentes en las columnas indican diferencias estadísticas, de acuerdo con la prueba de $\operatorname{Scott}-\operatorname{Knott}(\mathrm{p} \leq 0,05)$. 
Table 3. Area under the disease progress curve (AUDPC) of H. vastatrix in dry and rainy season in lower, middle, and upper part of $\mathrm{cv}$ Typica, in Chanchamayo, Junin-Peru, from April 2017 to March, 2018.

Tabla 3. Área bajo la curva del progreso de la enfermedad (AUDPC) de H. vastatrix en las estaciones húmeda y seca en la parte baja, media y alta de la planta del cv Typica, en Chanchamayo, Junín-Perú, de abril 2017 a marzo, 2018.

\begin{tabular}{|c|c|c|c|c|c|c|c|c|}
\hline \multirow[b]{2}{*}{ Genotypes } & \multicolumn{4}{|c|}{ Dry seasons } & \multicolumn{4}{|c|}{ Rainy seasons } \\
\hline & Lower & Middle & Upper & Sum & Lower & Middle & Upper & Sum \\
\hline UNACAF-97 & $2580 \mathrm{a}$ & $1668 \mathrm{~b}$ & $288 \mathrm{~d}$ & $4536 \mathrm{c}$ & $735 \mathrm{a}$ & $324 \mathrm{a}$ & $72 \mathrm{~b}$ & $1131 \mathrm{a}$ \\
\hline UNACAF-94 & $1551 \mathrm{c}$ & $804 \mathrm{~d}$ & $321 \mathrm{~d}$ & $2676 \mathrm{~d}$ & $438 \mathrm{~b}$ & $147 \mathrm{c}$ & $51 \mathrm{c}$ & $636 \mathrm{c}$ \\
\hline UNACAF-93 & $1095 \mathrm{~d}$ & $486 \mathrm{e}$ & $225 \mathrm{~d}$ & $1806 \mathrm{e}$ & $495 \mathrm{~b}$ & $261 \mathrm{~b}$ & 99 a & $855 \mathrm{~b}$ \\
\hline UNACAF-87 & $1821 \mathrm{~b}$ & $1332 \mathrm{c}$ & $552 \mathrm{c}$ & $3705 \mathrm{c}$ & $285 d$ & $150 \mathrm{c}$ & $30 \mathrm{c}$ & $465 \mathrm{~d}$ \\
\hline UNACAF-86 & $1164 \mathrm{~d}$ & 579 e & $252 \mathrm{~d}$ & $1995 \mathrm{e}$ & $141 \mathrm{e}$ & $69 \mathrm{e}$ & $0 \mathrm{~d}$ & $210 \mathrm{e}$ \\
\hline UNACAF-81 & $915 \mathrm{~d}$ & $672 d$ & $201 \mathrm{~d}$ & 1788 e & $180 \mathrm{e}$ & $75 \mathrm{e}$ & $0 \mathrm{~d}$ & $255 \mathrm{e}$ \\
\hline UNACAF-76 & 2442 a & $1476 \mathrm{c}$ & 846 b & $4764 \mathrm{~b}$ & $288 \mathrm{~d}$ & $105 \mathrm{~d}$ & $30 \mathrm{c}$ & $423 \mathrm{~d}$ \\
\hline UNACAF-52 & $1551 \mathrm{c}$ & 999 d & $354 \mathrm{~d}$ & $2904 \mathrm{~d}$ & $204 \mathrm{e}$ & $30 \mathrm{f}$ & $0 \mathrm{~d}$ & $234 \mathrm{e}$ \\
\hline UNACAF-40 & $915 \mathrm{~d}$ & $432 \mathrm{e}$ & $204 d$ & $1551 \mathrm{f}$ & $54 \mathrm{f}$ & $0 \mathrm{f}$ & $0 \mathrm{~d}$ & $54 \mathrm{~g}$ \\
\hline UNACAF-36 & $648 \mathrm{e}$ & $276 \mathrm{f}$ & $60 \mathrm{e}$ & $984 \mathrm{f}$ & $96 \mathrm{f}$ & $0 \mathrm{f}$ & $0 \mathrm{~d}$ & $96 \mathrm{f}$ \\
\hline UNACAF-27 & $927 \mathrm{~d}$ & $498 \mathrm{e}$ & $315 \mathrm{~d}$ & $1740 \mathrm{e}$ & $336 \mathrm{c}$ & $144 \mathrm{c}$ & $0 \mathrm{~d}$ & $480 \mathrm{~d}$ \\
\hline UNACAF-24a & $252 \mathrm{f}$ & $96 \mathrm{f}$ & $30 \mathrm{e}$ & $378 \mathrm{~g}$ & $0 \mathrm{~g}$ & $0 \mathrm{f}$ & $0 \mathrm{~d}$ & $0 \mathrm{~g}$ \\
\hline UNACAF-16 & $528 \mathrm{e}$ & $156 \mathrm{f}$ & $30 \mathrm{e}$ & $714 \mathrm{~g}$ & $96 \mathrm{f}$ & $0 \mathrm{f}$ & $0 \mathrm{~d}$ & $96 \mathrm{f}$ \\
\hline UNACAF-8 & $603 \mathrm{e}$ & $450 \mathrm{e}$ & $132 \mathrm{e}$ & $1155 \mathrm{f}$ & $0 \mathrm{~g}$ & $0 \mathrm{f}$ & $0 \mathrm{~d}$ & $0 \mathrm{~g}$ \\
\hline UNACAF-2 & $645 \mathrm{e}$ & $417 \mathrm{e}$ & $267 \mathrm{~d}$ & $1329 \mathrm{f}$ & $0 \mathrm{~g}$ & $0 \mathrm{f}$ & $6 \mathrm{~d}$ & $6 \mathrm{~g}$ \\
\hline UNACAF-104 & $750 \mathrm{e}$ & 387 e & $54 \mathrm{e}$ & $1191 \mathrm{f}$ & $336 \mathrm{c}$ & $108 \mathrm{~d}$ & $0 \mathrm{~d}$ & $444 d$ \\
\hline UNACAF-105 & $831 \mathrm{e}$ & $366 \mathrm{e}$ & $60 \mathrm{e}$ & $1257 \mathrm{f}$ & $360 \mathrm{c}$ & $126 \mathrm{~d}$ & $0 \mathrm{~d}$ & $486 \mathrm{~d}$ \\
\hline UNACAF-119 & $1047 \mathrm{c}$ & $558 \mathrm{e}$ & $138 \mathrm{e}$ & $1743 \mathrm{e}$ & $294 d$ & $108 \mathrm{~d}$ & $12 \mathrm{~d}$ & $414 d$ \\
\hline UNACAF-128 & $1308 \mathrm{c}$ & $888 \mathrm{~d}$ & $462 \mathrm{~d}$ & $2658 \mathrm{~d}$ & $162 \mathrm{~d}$ & $90 \mathrm{e}$ & $0 \mathrm{~d}$ & $252 \mathrm{e}$ \\
\hline UNACAF-132 & 2703 a & $1539 \mathrm{c}$ & $576 \mathrm{c}$ & $4818 \mathrm{~b}$ & $516 \mathrm{~b}$ & $189 \mathrm{c}$ & $36 \mathrm{c}$ & $741 \mathrm{~b}$ \\
\hline UNACAF-138 & $2445 \mathrm{a}$ & $1647 \mathrm{~b}$ & $840 \mathrm{~b}$ & $4932 \mathrm{~b}$ & $288 \mathrm{~d}$ & $141 \mathrm{c}$ & $0 \mathrm{~d}$ & $429 d$ \\
\hline UNACAF-140 & $1455 \mathrm{c}$ & $903 \mathrm{~d}$ & $318 \mathrm{~d}$ & $2676 \mathrm{~d}$ & $81 \mathrm{f}$ & $18 \mathrm{f}$ & $0 \mathrm{~d}$ & $99 \mathrm{f}$ \\
\hline UNACAF-158 & $0 \mathrm{f}$ & $0 \mathrm{f}$ & $0 \mathrm{e}$ & $0 \mathrm{~g}$ & $0 \mathrm{~g}$ & $0 \mathrm{f}$ & $0 \mathrm{~d}$ & $0 \mathrm{~g}$ \\
\hline UNACAF-162 & $294 \mathrm{f}$ & $72 \mathrm{f}$ & $0 \mathrm{e}$ & $366 \mathrm{~g}$ & $258 \mathrm{~d}$ & $42 \mathrm{e}$ & $0 \mathrm{~d}$ & $300 \mathrm{e}$ \\
\hline UNACAF-165 & 2112 b & $1284 \mathrm{c}$ & $699 \mathrm{c}$ & $4095 \mathrm{c}$ & $132 \mathrm{e}$ & $30 \mathrm{f}$ & $30 \mathrm{c}$ & $192 \mathrm{e}$ \\
\hline UNACAF-186 & 2004 b & $1200 \mathrm{c}$ & $636 \mathrm{c}$ & $3840 \mathrm{c}$ & $252 \mathrm{~d}$ & $66 \mathrm{e}$ & $39 \mathrm{c}$ & $357 \mathrm{e}$ \\
\hline UNACAF-214 & 2733 a & $1653 \mathrm{~b}$ & $939 \mathrm{~b}$ & $5325 \mathrm{a}$ & $198 \mathrm{e}$ & $123 \mathrm{~d}$ & $24 \mathrm{c}$ & $345 \mathrm{e}$ \\
\hline UNACAF-216 & $2280 \mathrm{~b}$ & $1293 \mathrm{c}$ & $603 c$ & $4176 \mathrm{c}$ & $150 \mathrm{e}$ & $66 \mathrm{e}$ & $33 \mathrm{c}$ & $249 \mathrm{e}$ \\
\hline UNACAF-218 & $1470 \mathrm{c}$ & $939 \mathrm{~d}$ & $453 \mathrm{~d}$ & $2862 \mathrm{~d}$ & $369 \mathrm{c}$ & $156 \mathrm{c}$ & $12 \mathrm{~d}$ & $537 \mathrm{c}$ \\
\hline UNACAF-226 & 2715 a & $1890 \mathrm{a}$ & 948 b & $5553 \mathrm{a}$ & $123 \mathrm{e}$ & $75 \mathrm{e}$ & $12 \mathrm{~d}$ & $210 \mathrm{e}$ \\
\hline UNACAF-228 & $2631 \mathrm{a}$ & $1485 \mathrm{c}$ & $678 \mathrm{c}$ & $4794 \mathrm{~b}$ & $171 \mathrm{e}$ & $75 \mathrm{e}$ & $30 \mathrm{c}$ & $276 \mathrm{e}$ \\
\hline UNACAF-199 & $2622 \mathrm{a}$ & $2001 \mathrm{a}$ & $1290 \mathrm{a}$ & $5913 \mathrm{a}$ & $75 \mathrm{e}$ & $48 \mathrm{e}$ & $30 \mathrm{c}$ & $153 \mathrm{f}$ \\
\hline Mean & 1470 & 888 & 399 & 2757 & 222 & 86 & 17 & 326 \\
\hline SE & 157 & 108 & 71 & 279 & 31 & 18 & 8 & 43 \\
\hline SD & 351 & 241 & 160 & 625 & 70 & 40 & 17 & 96 \\
\hline
\end{tabular}

Different letters within columns indicate significant differences according to Scott-Knott's test ( $\mathrm{p} \leq 0.05$ ). Sum: lower+middle+upper part / Letras diferentes en las columnas indican diferencias estadísticas, de acuerdo con la prueba de Scott-Knott ( $\mathrm{p} \leq 0,05)$. Suma: Parte baja+media+alta.

Although the study area showed adequate environmental conditions for the progress of $H$. vastatrix, it was observed that there were different degrees of severity and AUDPC in each genotype evaluated. For example, only 
in the dry season, UNACAF-199 (mean severity of $11.10 \%$; total AUDPC of 5913), UNACAF-214 (mean severity of 9.11; total AUDPC of 5325), and UNACAF-226 (mean severity of $9.87 \%$; total AUDPC of 5553) presented higher severity and AUDPC than UNACAF-24A (mean severity of $0.6 \%$; total AUDPC of 378), UNACAF-16 (mean severity of $1.11 \%$; total AUDPC of 714), UNACAF-158 (mean severity of $0 \%$; total AUDPC of 0 ) and UNACAF-162 (mean severity of $0.67 \%$; total AUDPC of 366) ( $\mathrm{p} \leq 0.05)$ (Table 2,3). This result suggests a certain tolerance of UNACAF-24A, UNACAF-16, UNACAF-158, and UNACAF-162 to CLR, as pointed out by Haddad et al. (2009) where the cultivation of coffee treated with fungicides showed low severity ( 0 to $1 \%)$. Also, other researchers as Madeira (2016) observed that the AUDPC of some cultivars of susceptible coffee to CLR as Catuaí 99, Catuaí 114, Catuaí 144, and Mundo Novo were 2242.53, 2363.27, 2742.94, and 2971.91.

\section{Conclusion}

In this work, two seasons were determined (dry and rainy) with different severity of coffe leaf rust (CLR) and area under the disease progress curve (AUDPC). In dry season, the coffee genotypes showed high severity and AUDPC, meanwhile, in the rainy seasons the severity and AUDCP decreased. Also, in both seasons it was observed that severity and AUDPC gradually decrease from the bottom to the top (lower> middle> upper). Furthermore, the genotypes UNACAF-24A, UNACAF-16, UNACAF-158 and UNACAF-162 presented a mean severity of $0.6 \%$, $1.11 \%, 0 \%$, and $0.67 \%$, respectively, and AUDPC of 378, 714,0, and 366, respectively. Finally, further studies are suggest to find new genetic materials to combat CLR.

\section{Acknowledgements}

The authors want to acknowledgement to Universidad Nacional Agraria La Molina for the support in the study.

\section{Authors' contributions}

Ricardo Borjas-Ventura, Leonel Alvarado-Huamán and Alberto Julca-Otinano contributed with the data analysis. Viviana Castro-Cépero, Liliana García-Nieves and Jorge Jimenez-Dávalos collected the samplings in field. All the authors helped to conceive and comment on the manuscript.

\section{Cited literature}

Alvarado, L., R., Vértiz, R. Borjas, V. Castro, y A. Julca. 2017. Caracterización agronómica de 95 accesiones en el banco de germoplasma de café en Chanchamayo (Perú), año 2016. Rev. ECIPerú 14:41-48. doi:10.33017/RevECIPeru2017.0004

Avelino, J., M. Cristancho, S. Georgiou, P. Imbach, L. Aguilar, G. Bornemann, P. Laderach, F. Anzueto, A. Hruska, and C. Morales. 2015. The coffee rust crises in Colombia and Central America (2008-2013): impacts, plausible causes and proposed solutions. Food Sec. 7:303-321. doi:10.1007/s12571-015-0446-9

Avelino, J., L. Willocquet, and S. Savary. 2004. Effects of crop management patterns on coffee rust epidemic. Plant Pathol. 53:541-547. doi:10.1111/j.1365-3059.2004.01067.x

Barbosa, J., e M. Junior. 2010. Agrostat-Sistema para análises estatísticas de ensaios agronônomicos. Versão 1.0. Universidade Estadual Paulista (UNESP), Jaboticabal, BRA. 
Brinate, S.V.B., L.D. Martins, W.N. Rodrigues, T.V. Colodetti, V.V. Cunha, G.N.P. Rosa, W.C.J. Junior, and M.A. Tomaz. 2015. Influence of cupper sources on the management of leaf rust, growth and crop yield of Arabica coffee. J. Food Agric. Environ. 13:184-189. doi:10.1234/4.2015.3983

Capucho, A., L. Zambolim, U.N. Lopes, and N.S. Milagres. 2013. Chemical control of coffee rust in Coffea canephora cv Conilon. Australas. Plant Pathol. 42:667-673. doi:10.1007/s13313-013-0242-y

Carré-Missio, V., F. Rodrigues, D. Schurt, R. Resende, N. Souza, D. Rezende, W. Moreira, and L. Zambolim. 2013. Effect of foliar-applied potassium silicate on coffee leaf infection by Hemileia vastatrix. Ann. Appl. Biol. 164:396-403. doi:10.1111/aab.12109

Chemura, A., O. Mutanga, M. Sibanda, and P. Chidoko. 2018. Machine learning prediction of coffee rust severity on leaves using spectroradiometer data. Trop. Plant Pathol. 43(2):11-127. doi:10.1007/s40858-017-0187-8

Dias, R.A., M.R. Ribeiro, A.M. Carvalho, C.E. Botelho, A.G. Mendes, A.D. Ferreira, and F.C. Fernandes. 2019. Selection of coffee progenies for resistance to leaf rust and favorable agronomic traits. Coffee Sci. 14:173-182. doi:10.25186/ cs.v14i2.1564

Díaz, C. y Carmen, M. 2017. Línea base del sector café en el Perú. Programa de las Naciones Unidas para el Desarrollo (PNUD), Lima, Perú.

Haile, M. 2018. A review on impacts of climatic variability on Arabica coffee improvement in Ethiopia. Int. J. Fores. Hortic. 4(1):9-18. doi:10.20431/2454-9487.0401002

Haddad, F., L.A. Maffia, E.S.G. Mizubuti, and H. Teixeira. 2009. Biological control of coffee rust by antagonistic bacteria under field conditions in Brazil. Biol. Control 49:114-119. doi:10.1016/j.biocontrol.2009.02.004

Honorato-Junior, J., L. Zambolim, C.E. Aucique-Pérez, R. Resende, and F.A. Rodrigues. 2015. Photosynthetic and antioxidative alterations in coffee leaves caused by epoxiconazole and pyraclostrobin sprays and Hemileia vastatrix infection. Pest. Biochem. Physiol. 123:31-39. doi:10.1016/j.pestbp.2015.01.016

INEI (Instituto Nacional de Estadística e Informática). 2014. Compendio estadístico Perú 2014. INEI, PER. https://www.inei. gob.pe/media/MenuRecursivo/publicaciones_digitales/Est/Lib1173/cap12/cap12.pdf (consultado 15 sep. 2019).

ICO (International Coffee Organization). 2019. Total production by all exporting countries. ICO, London, GBR. http://www.ico. org/prices/po-production.pdf (accessed Sep. 10, 2019).

Julca, A., R. Borjas, L. Alvarado, N. Julca, V. Castro, y S. Bello. 2019. Relación entre la incidencia y severidad de la roya del café (Hemileia vastatrix) en San Ramón, Chanchamayo. Rev. Cienc. Invest. 4(4):1-9. doi:10.5281/zenodo.3477556

Julca, A., C. Echevarria, Y. Ladera, R. Borjas, R. Cruz, S. Bello, y R. Crespo. 2013. Una revisión sobre la roya del café (Hemileia vastatrix) algunas experiencias y recomendaciones para el Perú. Universidad Nacional Agraria La Molina, Lima, PER.

Julca, A., Y. Ladera, L. Alvarado, R. Borjas, J. Vásquez, C. García, J. Jimémez, y V. Castro. 2018. Comportamiento de variedades brasileras en el banco de germoplasma de café en San Ramón-Chanchamayo. Universidad Nacional Agraria La Molina, Lima, PER.

Klein, A., I. Steffan-Dewenter, and T. Tscharntke. 2003. Bee pollination and fruit set of coffea arabica and C. canephora (Rubiaceae). Am. J. Bot. 90:153-157. doi:10.3732/ajb.90.1.153

López-Bravo, D., E. Virginio-Filho, and J. Avelino. 2012. Shade is conductive to coffee rust as compared to full sun exposure under standardized fruit load conditions. Crop Protec. 38:21-29. doi:10.1016/j.cropro.2012.03.011

Madden, L., G. Hughes, and F. Van-den-Bosch. 2007. The study of plant disease epidemics. American Phytopathology Society, St. Paul, MN, USA. 
Madeira, J. 2016. Reação de genétipos de cafeeiro à Hemileia vastatrix e à Cercospora caffeicola. Master Science dissertation. Universidade Federal de Uberlândia, Minas Gerais, BRA.

Marca-Huamancha, C., R. Borjas-Ventura, D. Rebaza-Fernández, S. Bello-Amez, y A. Julca-Otiniano. 2018. Efecto de la fertilización mineral y de un fertilizante biológico en piña (Ananas comosus L. Merr) cultivar MD2. Rev. Colomb. Cienc. Hortíc. 12:59-68. doi:10.17584/rcch.2018v12i1.7901

Matos, C., A. Pereira, B. Pereira, V. Carvalho, e R. Silva. 2019. Evolução e monitoramento da ferrugem (Hemileia vastatrix) no sul de Minas Gerais. X Simposio de Pesquisa dos Cafés do Brasil, BRA. http://www.consorciopesquisacafe.com.br/ojs/ index.php/SimposioCafe2019/article/view/214/104 (consultado 10 oct. 2019).

MINAGRI (Ministerio de Agricultura y Riego). 2019. Situación actual del café en el país. MINAGRI, PER. http://minagri.gob. pe/portal/485-feria-scaa/10775-el-cafe-peruano (consultado 5 oct. 2019).

Rice, R. 2018. Coffee in the crosshairs of climate change: agroforestry as abatis. Agroecol. Sust. Food Syst. 42:1058-1076. doi: $10.1080 / 21683565.2018 .1476428$

Santana, F., L. Rocha, P. Nitsche, e P. Caramori. 2015. Monitoramento de doenças do cafeeiro nas safras 2012-2013 e 20132014 em londrina-pr. Apresntado em: IX Simpósio de Pesquisa dos Cafés do Brasil: inovação no conteúdo e no formato inaugura nova tendência de apresentação da pesquisa. Embrapa Café, Curitiba, Paraná, BRA. 24 a 26 de junho.

Sera, G., T. Sera, I.C. Fonseca, e D. Ito. 2009. Resistência ferrugem alaranjada em cultivares de café. Coffee Sci. 5(1):59-66. doi:10.25186/cs.v5i1.272

Subroto, G., D. Kusbianto, S. Avivi, S. Slameto, and S. Setiyono. 2019. Correlation of secondary metabolites of leaf with resistance to Leaf Rust (Hemileia vastatrix) on several Arabica coffee clones. Ilmu Pertanian 4(2):71-75.

Talhinhas, P., D. Batista, I. Diniz, A. Vieira, D. Silva, A. Loureiro, S. Tavares, A. Pereira, H. Azinheira, L. Guerra-Guimaraes, V. Varzea, and M.D.C. Silva. 2017. The coffee leaf rust pathogen Hemileia vastatrix: one and half centuries around the topics. Mol. Plant Pathol. 18:1039-1051. doi:10.1111/mpp.12512

Toniutti, L., J. Breitler, H. Etienne, C. Campa, S. Doulbeau, L. Urban, C. Lambot, J. Pinilla, and B. Bertrand. 2017. Influence of environmental conditions and genetic background of arabica coffee (Coffea arabica) on leaf rust (Hemileia vastatrix) pathogenesis. Front. Plant Sci. 8:2025. doi:10.3389/fpls.2017.02025

Zambolim, L. 2016. Current status and management of coffee leaf rust in Brazil. Trop. Plant Pathol. 41:1-8. doi:10.1007/s40858016-0065-9 